\title{
PEMBINAAN KELUARGA MUALAF UPAYA MEMBENTUK PRIBADI MUSLIM
}

\author{
Mahmud Mahmud \\ UIN Sunan Gunung Djati Bandung \\ E-Mail:mahmud@uinsgd.ac.id \\ Miftahul Fikri \\ UIN Sunan Gunung Djati Bandung \\ E-Mail:miftahulfikrisiwa@uinsgd.ac.id \\ Hasbiyallah Hasbiyallah \\ UIN Sunan Gunung Djati Bandung \\ E-Mail: hasbiyallah@uinsgd.ac.id \\ Anita Nuraeni \\ UIN Sunan Gunung Djati Bandung \\ E-Mail: nitachan49@gmail.com
}

\begin{tabular}{|c|c|c|}
\hline Received & Revised & Accepted \\
\hline 4 July 2019 & 2 Agustus 2019 & 20 Agustus 2019 \\
\hline
\end{tabular}

\section{THE COACHING OF MUALLAF FAMILY TO CREATE MUSLIM PERSONAL}

\section{Abstract:}

This article was conducted to see how far the religious formation of the converts was obtained. Because as a muslim who is new to Islam, certainly requires a religious formation to make it easier for him to understand the teachings about Islam. It aims to be able to describe how religious formation is carried out by family converts and how the results o religious formation convert to Islam, which is in accordance with Muslims in general. So that this research can be a role model for the community in carrying out religious guidance on converts. This research method uses a qualitative approach with the method of description analysis to find out more about the implementation of religious coaching for several families of convert families. The results of this study show how the process of fostering Islamic religious education carried out by several convert families in several ways and methods to increase the 
firmness of their faith in Islam. So as to make their faith strong and make a muslim person intact and to avoid their return to their old beliefs.

Keywords: mualaf, religious formation, and Islam

\begin{abstract}
Abstrak:
Artikel ini dilakukan untuk melihat sejauh mana pembinaan keagamaan para mualaf didapatkan. Karena sebagai seorang muslim yang baru mengenal Islam, tentu membutuhkan sebuah pembinaan keagamaan agar memudahkannya dalam memahami ajaran-ajaran tentang Islam. Hal ini bertujuan untuk dapat mendeskripsikan bagaimana pembinaan keagamaan yang dilakukan oleh keluarga mualaf dan bagaimana hasil dari pembinaan keagamaan mualaf terhadap agama Islam, yang sesuai dengan muslim pada umumnya. Sehingga penelitian ini dapat menjadi role model masyarakat dalam melakukan pembinaan keagamaan terhadap mualaf. Metode penelitian ini menggunakan pendekatan kualitatif dengan metode analisis deskripsi untuk mengetahui lebih jauh tentang pelaksanaan pembinaan keagamaan bagi beberapa keluarga keluarga Mualaf. Hasil dari penelitian ini menunjukkan bagaimana proses pembinaan pendidikan agama Islam yang dilakukan oleh beberapa keluarga mualaf dengan beberapa cara dan metode untuk meningkatkan keteguhan iman mereka terhadap agama Islam. Sehingga menjadikan keimanan mereka kokoh dan menjadikan pribadi seorang muslim yang utuh dan agar terhindar dari kembalinya mereka kepada kepercayannya yang lama.
\end{abstract}

Kata kunci: mualaf, pembinaan keagamaan, dan Islam

\title{
Pendahuluan
}

Agama adalah salah satu hal yang paling banyak dibicarakan oleh masyarakat sekitar. Hal ini terlihat dari bagaimana fungsi agama itu tersendiri sebagai pedoman hidup yang dijadikan petunjuk untuk menjalani kehidupan manusia, yang terjadi pada dewasa ini yaitu mengenai pertumbuhan pemeluk agama yang menurut Pew Reaserch Center yang dikutip oleh Ida Rahmawati menyebutkan bahwa tingkat pertumbuhan yang paling tinggi didunia adalah agama Islam '. Peningkatan pertumbuhan agama ini dipicu oleh banyanya masyarakat yang sebelumnya nonmuslim memilih untuk merubah keyakinan mereka untuk menjadi seorang muslim (mualaf). Hal ini pun terjadi di Indonesia yang dapat dilihat dari data MCI (Mualaf Center Indonesia) sebagai lembaga yang menaungi pembinaan mualaf di Indonesia mencatat setidaknya pada akhir 2018 ada 3.581 masyarakat Indonesia yang berpindah agama menjadi seorang muslim., dari data tersebut dapat diperkirakan jumlah mulaf bertambah $5-6 \%$ setiap tahunnya ${ }^{2}$.

\footnotetext{
${ }^{1}$ Ida Rahmawati and Dinie Ratri Desiningrum, “PENGALAMAN MENJADI MUALAF : SEBUAH INTERPRETATIVE PHENOMENOLOGICAL ANALYSIS THE EXPERIENCE OF BEING CONVERTED ( MUALAF ): AN INTERPRETATIVE PHENOMENOLOGICAL ANALYSIS" 7, no. Nomor 1 (2018).

${ }^{2}$ Hazliyasyah, “MCl Catat Pertumbuhan Mualaf Di 2016 Mencapai 2.491 Orang,” Republika, 2016.
} 
Hal ini dapat dipahami dengan bagaimana mereka dapat meyakini suatu keyakinan yang mereka pegang untuk dijadikan sebagai pegangan hidup mereka. Karena agama merupakan sebuah pilihan bagi seseorang. Sehingga ketika memutuskan untuk merubah keyakinan mereka dari agama yang lama ke dalam agama yang baru, maka mereka harus meninggalkan semua kebiasaan yang dilakukan sesuai ketentuaan keyakinannya yang lama dan beradaptasi untuk mengikuti aturan baru sesuai dengan keyakinan yang dianutnya. Salah satu alasan mengapa mereka merubah keyakinan mereka adalah untuk mengetahui dan mencari kebenaran tentang Tuhan. Sehingga ketika mereka tidak menemukan titik terang tentang ketuhanan yang mereka yakini sebelumnya, mereka mulai berpikir ulang dalam meyakini dan memahami tentang agama yang mereka anut. Karena proses dalam perubahan keyakinan tersebut mengalami fase yang terkadang dapat menyulitkan dalam merubah keyakinan sebelumnya terhadap keyakinan yang baru.

Dari pembahasan tersebut ditemukan bahwa ada sebuah penelitian yang membahas terkait dengan pembinaan keagamaan bagi orangtua mualaf yang dilakukan oleh Waenoful dengan judul "Kesulitan Orang Tua Mualaf Dalam Memberikan Pendidikan Agama Islam Kepada Anaknya Yang Remaja Di Yogyakarta",dalam penelitian ini membahas bagaimana pelaksanaan pendidikan keagamaan yang dilakukan oleh orangtua mualaf terhadap anaknya dan kesulitan pada pelaksanakaan pendidikan keagamaannya. Dalam pembahasannya tersebut sebagai orangtua, mereka memberikan fasilitas pendidikan keagamaan dengan menyekolahkan anak-anak mereka di sekolah berbasis Islam, dan juga sering melakukan diskusi terkait dengan keagamaan dan memberikan contoh keteladanan terhadap anak-anaknya.

Dalam penelitian tersebut mengungkapkan bahwa jika seorang mualaf setelah bersyahadat dan masih lemah aqidahnya. Lemah aqidahnya dapat terlihat dari pengalaman syariat Islam yang masih belum maksimal seperti ibadanya (sholat, zakat, puasa dan lainnya) belum dilaksanakan secara konsisten, akhlakul karimahmnya belum mapan. Berarti mualaf tersebut perlu adanya pembinaan atau bimbingan. Namun, jika seorang mualaf itu aqidahnya sudah kokoh dan kuat serta pengalaman dalam syari'at Islamnya sudah istiqomah maka orang tersebut bukan lagi dikatakan sebagai mualaf ${ }^{3}$.

Namun sebagai orang tua mualaf, mereka merasa kesulitan dalam mempelajari dan mengajarkan tentang agama Islam. Mengingat bahwa pendidikan keagamaan yang diberikan dalam keluarga mereka berbeda dengan keluarga yang sudah muslim sejak lahir. Karena mereka harus beradaptasi dengan kebiasaan baru yang sesuai dengan ajaran Islam, dan meninggalkan kebiasaan lamanya yang sesuai dengan agama sebelumnya. Hal ini nampak adanya beberapa faktor yang mempengaruhi terhadap proses penyesuaian dirinya, diantaranya adalah, faktor lingkungan keluarga, kerabat yang kurang mendukung terhadap keputusan yang diambil oleh keluarga mualaf tersebut. Maka hal ini menjadi sebuah hambatan yang dihadapi oleh keluarga mualaf dalam proses mempelajari ajaran agama Islam.

\footnotetext{
${ }^{3}$ Waenoful, "Kesulitan Orang Tua Mualaf Dalam Memberikan Pendidikan Agama Islam Kepada Anaknya Yang Remaja Di Yogyakarta” (UIN Sunan Kali Jaga, 2016).
} 
Ada juga beberapa penelitian yang menjelaskan tentang pola pendidikan agama Islam. Pola pendidikan tersebut dapat disesuaikan dengan kondisi mualaf. Hasil dari beberapa penelitian terkait dengan pola pendidikan keagamaan dapat dijadikan sendaran dalam konsep pendidikan agama Islam, diantaranya adalah:

Pertama, bimbingan keagamaan mualaf dilaksanakan untuk menanamkan konsep-konsep keagamaan islam dan juga untuk merubah konsep keagamaan yang terdahulunya untuk disesuai dengan ajaran Islam ${ }^{4}$. Di dalam penelitiannya Hakim menjelaskan bahwa ketika seseorang mengalami konversi agama sering kali mereka masih bersikap dan berperilaku yang sesuai dengan konsep agama lamanya, dan belum bisa menyesuaikan dengan konsep agama barunya. Hal ini karena mereka sering beranggapan bahwa inti dari konsep semua agama itu sama, namun peraturannya yang berbeda. Sehingga diadakannya penanaman konsep-konsep keimanan yang sesuai dengan ajaran Islam ini agar para mualaf dapat menjalankan ajaran agamanya dengan baik, terutama terhadap sesuatu yang berhubungan dengan kewajiban yang hrus dilaksanakan sebagai seorang muslim. dengan demikan akan menjadikan sebuah keimanan yang kokoh bag mereka dan dapat menghindari dari berbagai macam cobaan atau terpaan yang akan menjadikannya kembali ke agama lamanya.

Kedua, adanya pelaksanaan dakwah konseling Islam yang dilakukan secara perorangan atau kelompok, hal ini bertujuan untuk memberikan masukan-masukan atau solusi yang baik dan sesuai. Sehingga mereka tidak merasa khawatir terhadap goncangan psikologis yang sangat rentan bagi mereka ${ }^{5}$. Dalam pemberian bimbingan dengan dakwah konseling ini menjadikan para mulaf dapat terbuka terkait dengan psikologis yang dialaminya selam masa konversi agama. Hal ini yang menjadikan harus adanya kajian secara empirik dan juga konseptual agar dapat diterapkan pada diri mualaf itu sendiri agar menjadi lebih baik,agar mereka dapat berkonsultasi dengan pihak tertentu terkait dengan psikologis ataupun masalah yang mereka alami. Sehingga dapat membentuk pribadi seorang muslim yang kuat.

Ketiga, memberikan pemahaman keagamaan bagi mualaf, pemahaman keagamaan ini meliputi akidah, dan segala sesuatu yang berkaitan dengan ajaran Islam. Pemberian pemahaman ini mempunyai tujuan yang sesuai dengan pokok materi agama. ${ }^{6}$. Dengan pemahaman keagamaan ini meliputi pemberian materi terkait dengan ajaran Islam, hal ini dapat dijadikan sebagai peneneman dasar-dasar kegamaan seperti tentang ketauhidan. Penanaman pemahaman tentang dasar keagaman ini akan memberikan sebuah pengertian terhadap mereka bahwa satu hal yang paling utama dalam ajaran Islam adalah mengimani bahwa hanya Allah lah Tuhan yang patut disembah. Dengan demkian ketika pemahaman mereka sudah meliputi seluruh ajaran Islam, mereka akan dengan mudah melaksanakan segala peraturan dalam ajaran Islam.

Keempat, memberikan metode yang sesuai dan berhubungan dengan psikologi agar dapat memberikan kemudahan pada mualaf dalam memperdalam ajaran Islam,

\footnotetext{
${ }^{4}$ Ramlah Hakim, “Pola Pembinaan Muallaf Di Kabupaten Sidrap Provinsi Sulawesi Selatan,” 2013, 85-96.

${ }^{5}$ Sri Hidayati, “DI KOTA SINGKAWANG DAN SOLUSINYA" XV, no. 1 (2014): 111-36.

${ }^{6}$ Wan Mohd et al., "Penerimaan Penggunaan Istilah Mualaf Dalam Kalangan Mualaf Di Malaysia" 6 (2015): 111-34.
} 
yaitu 1) personal approach method, 2) speech method, 3) khalaqah method, 4) consultation and advocation method, dan 5) audio visual method ${ }^{7}$. Dari beberapa metode diatas dalam dipahami bahwa penggunaan metode dalam pembinaan keagamaan bagi mualaf ini disesuaikan dengan kondisi dan situasi dari mualaf itu sendiri. Hal ini dilakukan agar mencakup terhadap aspek psikologis dari mualaf itu sendiri yang menjadi acuan dalam memilih metode tersebut. Dengan demikian akan memberikan kemudahan bagi mereka dalam mempelajari ajaran Islam.

Ketika menjadi seorang mualaf tentunya mereka merasa kesulitan untuk melaksanakan segala perintah yang diajarkan dalam agama Islam. Hal ini karena kurangnya pemahaman mereka tehadap agama Islam. Sebagai saudara muslim kita harus memperhatikan keberadan mualaf sebagai upaya dalam memberikan sebuah pembinaan keagamaan bagi mereka yang baru mengenal Islam. Agar mereka tidak merasa kebingungan bahkan merasa terasingkan oleh sesama muslim.

Hal ini terjadi pada beberapa keluarga yang memutuskan untuk menjadi mualaf. Mereka memutuskan untuk merubah keyakinan mereka sebelumnya yang beragama Kristen untuk menjadi seorang muslim. Keluarga yang terdiri dari ayah, ibu dan anak ini memiliki alasan yang berbeda-beda dalam memutuskan merubah keyakinannya, dengan waktu yang berbeda-beda ketika memeluk agama Islam. Sebagai keluarga yang baru saja mengenal Islam tentunya sebagai orang tua mereka merasa kesulitan bagaimana mengajarkan keagamaan bagi anak-anaknya karena minimnya pengetahuan tentang Islam. Hal ini menjadikan orang tua untuk mencari cara lain dalam mengembangkan keagamaan keluarganya diluar batas kemampuannya.

Dari pembinaan keagamaan yang dilakukan oleh para mualaf akan menjadikan keyakinan mualaf tersebut menjadi lebih yakin terhadap ajaran Islam, sehingga menjadikan mereka sebagai muslim yang utuh yang mengimani segala ajaran dan aturan yang ada dalam agama Islam. Hal ini seperti yang disebutkan didalam surah al-Anfal ayat 2-4 yang artinya, "seseungguhnya orang-orang yang beriman ialah mereka yang bila disebut nama Allah gemetarlah hati mereka, dan apabila dbacakan ayat-ayat-Nya bertambah iman mereka (karenanya, dan hanya kepada Tuhanlah mereka bertaqwa. (yaitu) orang-orang yang mendirikan sholat dan menafkahkan sebgaian dari rezeki yang Kam berikan kepada mereka. Itulah orng-orng yang beriman dengan sebenar-benarnya. Mereka akan memperoleh beberapa derajat ketingian di sisi Tuhannya dan ampunan serta rezeki (nimat) yang mulia", terkait degan ayat tersebut, maka indikator keimanan seseorang ${ }^{8}$ diantaranya adalah :

1. Bergetar hati mereka apabila menyebut nama Allah

2. Bertambah iman mereka ketika membaca al-Qur'an

3. Bertaqwa hanya kepada Allah

4. Melaksanakan sholat

5. Menafkahkan sebagian dari rezekinya

Maka berdasarkan penjelasan tersebut, penelitian ini penting dilaksanakan karena bertujuan sebagai sarana untuk mengetahui pembinaan kegamaan Islam

\footnotetext{
${ }^{7}$ Ansfiksia Eka and Poetra Yudha, "MUALAF CENTER DESIGN AS AN IMPLEMENTATION OF PSYCHOLOGICAL" 4, no. June (2016): 37-43.

${ }^{8}$ Sodikin, "Ini Ciri-Ciri Orang Beriman Yang Sesungguhnya," Islam Pos, 2017.
} 
yang dilakukan oleh keluarga Mualaf dan bagaimana hasil yang telah mereka dapatkan dari pembinaan keagamaan yang mereka lakukan. Sehingga bisa menjadikan Mualaf untuk meningkatkan pengetahuan dan pemahaman tentang ajaran Islam, keimanannya menjadi istiqomah, dan juga memberikan pengaruh kepedulian terhadap masyarakat yang berada disekitar mereka agar dapat membantu dalam mempelajari agama Islam, sehingga menjadikan para mualaf berkepribadian muslim yang utuh, dan tidak lagi bimbang tentang keyakinannya.

\section{Metode Penelitian}

Dalam penelitian ini menggunakan pendekatan kualitatif yang dibantu dengan metode analisis deskriptif. Hal ini karena penelitian ini untuk menunjukkan atau menggambarkan pembinaan pendidikan keagamaan oleh beberapa keluarga mualaf. Dengan metode ini peneliti akan menggambarkan tentang kondisi pembinaan keagamaan yang dilaksanakan para mualaf secara jelas, yang bersumber dari data yang dikumpulkan baik secara tulisan maupun lisan yang berasal dari subjek penelitian.

Sumber data penelitian ini berdasarkan empat keluarga mualaf yang menjadi subjek dalam penelitian. Keempat keluarga tersebut terdiri dari keluarga inti yaitu ayah, ibu, dan anak. Namun, ada pula yang hanya terdiri dari seorang suami muslim dan istri yang mualaf. Maka untuk mendapatkan informasi terkait dengan permasalahan yang diangkat dibutuhkan beberapa narasumber sebagai sumber data dalam mengumpulkan informasi terkait, sumber data tersebut dapat dilihat sebagai berikut :

Tabel 1 Sumber Data Penelitian

\begin{tabular}{|c|c|c|c|c|}
\hline No & Nama & Usia & Pekerjaan & $\begin{array}{c}\text { Lama Menjadi } \\
\text { Mualaf }\end{array}$ \\
\hline 1. & LT & 48 Thn & Pegawai Swasta & 19 Tahun \\
\hline 2. & HK & 47 Thn & Ibu Rumah Tangga & 4 Tahun \\
\hline 3. & LR & 22 Thn & Mahasiswa & 4 Tahun \\
\hline 4. & RK & 40 Thn & Ibu Rumah Tangga & 5 Tahun \\
\hline 5. & RA & 19 Thn & Mahasiswa & 4 Tahun \\
\hline
\end{tabular}

Berdasarkan tabel 1, dijelaskan bahwa ada dua keluarga mualaf yang menjadi sumber data dari penelitian ini. Yaitu satu keluarga yang terdiri dari orangtua dan seorang anak, dan satu keluarga terdiri dari seorang ibu dan seorang anak. Penelitian ini menggunakan teknik pengumpulan data dengan cara observasi dan juga wawancara untuk mengumpulkan informasi terkait dengan fakta-fakta dalam pembelajaran pendidikan agama Islam pada keularga mualaf. Adapun dalam penelitian ini, subjek penelitian diberikan beberapa pertanyaan yang berkaitan dengan fokus permasalahan penelitian yang diajukan. Karena secara tidak langsung 
subjek penelitian tersebut merasakan bagaimana proses pembinaan keagamaan Islam yang mereka pelajari selama menjadi mualaf.

Pada tahap selanjutnya dilakukan analisis data yang menggunakan model Miles dan Huberman yang dilakukan secara interaktif dan terus-menerus sehingga datanya sudah sesuai dengan permasalahan peneltian. Ada tiga tahap proses analasis data , yaitu data reduction (reduksi data), data display (penyajian data), dan conclusion drawing/verification (kesimpulan data/ verifikasi data).

\section{Hasil Penelitian dan Pembahasan \\ Hasil \\ KM 1}

Keluarga yang terdiri dari orang tua dan tiga orang anak ini, mengalami suatu proses konversi agama yang terjadi kepada orang tua dan anak sulungnya, sedangkan kedua anaknya susah mengikuti keyaknan sang ayah sedari kecil. Keluarga yang awalnya beragama Kristen Protestan ini menerangkan bahwa mereka memutuskan untuk berpindah keyakinan mereka terkait dengan beberapa hal yang berbeda. Bagi pak LT selaku kepala keluarga mengungkapkan bahwa memilih untuk menjadi seorang mualaf pada tahun 2000. Hal ini terjadi karena adanya dorongan keingintahuan tentang ajaran islam itu sendiri. beliau mulai tertarik ketika melihat anak-anak yang belajar mengaji dimesjid dekat rumahnya, beliau meliau bahwa anak-anak begitu bersemangat belajar tulisan arab yang menurutnya mempunyai tingkat keulitan yang tinggi, namun anak-anak tersebut tidak berhenti semangat untuk belajar mengaji.

Sedangkan untuk Istri dan anak sulungnya mereka merubah keyakinan mereka di tahun 2015. Perpindahan agama yang dialami oleh sang istri diakibatkan karena pertanyaan putra bungsunya yang menyadarkan bahwa adanya perbedaan antara sang ibu dengan ibu temannya yang seorang muslim pada umumnya. Pertanyaan itulah yang membuat sang ibu mulai berpikir bahwa putra bungsunya tidak memahami perbedaan agama diantara kedua orangtuanya. Sehingga sang ibu mulai mencari tahu tentang ajaran-ajaran Islam di artikel-artikel keislaman secara sendiri. Dan menjadikan keyakinan dalam hati bahwa agama Islam merupakan ajaran yang benar.

Bagi putri sulungnya, ia berpikir untuk merubah keyakinannya ketika ia mendapatkan pertanyaan bahwa ajaran islam itu keras, rasis, dan radikal. Ia mulai bepikir dan mencari tahu tentang kebenaran dari pernyataan tersebut. Namuna, ketia ia sedang mencari tentang kebenaran tersebut ia malah merasakan sebaliknya ia merasa bahwa ajaran Islam bukan ajaran yang mengajarkan hal-hal yang seperti itu, melainkan mengajarkan sesuatu yang memberikan kemashlahatan bagi umat manusia. Hal ituah yang memberikan bantahan tentang pernyataan itu dan membuat ia terbuka untuk mengenal Islam lebih dalam.

Sebagai kepala keluarga yang pertama kali mengenal Islam, beliau tidak pernah memaksa keluarganya untuk mengikuti keyakinannya yang baru. Beliau hanya ingin keluarganya mempunyai agama yang sesuai dengan keyakinan hatinya. Namun 
ternyata Allah berkendak lain, Allah mengirimkan hidayah-Nya untuk Istri dan anaknya, sehingga mereka memantapkan keinginannya untuk merubah keyakinan mereka menjadi seorang muslim.

Bagi pak LT sendiri beliau mendapatkan pembinaan keagamaan dari seorang ustadz yang berada disekitar rumahnya yang bersedia mengajarkan tentang ajaran Islam kepadanya. Beliau mendapatkan pembinaan kurang lebih selam dua tahun. Dari sana beliau mendapatkan pengarahan tentang ketauhidan, aqidah, akhlak, syari'ah, tatacara melaksanakan ibadah seperti sholat, puasa, dan membaca al Qur'an. Selain mendapatkan pembinaan dari tokoh agama setempat beliau sering mengunjungi tempat kajian-kajian Islam yang membahas seputar ajaran Islam.

Dari bekal keagamaan seperti itulah pak LT mengajarkan keluarganya tentang agama dengan memberikan sebuah contoh teladan yang ditunjukkan dengan tingkah laku sehari-hari seperti, segera melaksanakan sholat setelah adzan berkumandang, mengaji walaupun terbata-bata, bersabar dalam suatu hal, menjalankan puasa, mengajarkan untuk menutup aurat, mengajak berdiskusi selepas magrib, dan mengajak ke acara atau kegiatan bertajuk Islami.

Dari beberapa hal diatas adalah pola pendidikan yang diajarkan oleh pak LT kepada keluarganya. Mengingat bahwa masih kurangnya pengetahuan beliau tentang ajaran Islam, beliau tidak hanya tinggal diam untuk memberikan pendidikan keagamaan bagi keluarganya. Dengan hal itulah beliau mengajarkan keluarganya tentang Islam. Dari pelaksanaan pembinaan tersebut menjadikan keluarga ini menemukan titik terang tentang kebenaran tentang Tuhan, dan juga menjadikan mereka lebih meyakini terhadap ajaran Islam, yang memberikan sebuah keselarasan hidup di dunia dan juga di akhirat.

KM 2

Keluarga yang terdiri dari seorang Ibu dan seorang anak ini mualnya beragama Khatolik. Namun, mereka merubah keyakinan mereka menjadi seorang muslim dengan beberapa hal yang berbeda. Perpindahan agama ini diawali oleh sang ibu, pada tahun 2014 sang ibu memutuskan untuk merubah keyakinannya ketika ia sedang mengalami sebuah permasalahan dalam hubungan rumah tangganya. Ketika ia memutuskan untuk bercerai ada beberapa hal yang mengganjal mengenai perceraian yang akan diajukannya. Beliau memaparkan bahwa di dalam agama Khatolik tidak ada namanya perceraian yang dan hanyalah pisah ranjang. Yang menurutnya itu adalah sesuatu yang tidak adil. Karena bagaimana jika hubungan suami istri yang penuh dengan konflik dan satu-satunya jalan terbaik berpisah, mereka harus tetap tinggal dalam satu rumah. Tidak saling berkomuniksi, bahkan yang lebih parahnya adalah adanya perselingkuhan dan perzinaan karena kebutuhan seksual mereka harus terpenuhi.

Dari hal itulah yang membuatnya ragu terhadap agama yang ia anut, karena tidak danya solusi terbaik dari permasalahan yang dialaminya. Sehingga ia meminta solusi kepada asaudaranya yang beragama Islam. Dari sanalah ia menemukan titik terang bahwa dalam ajaran agama Islam, menjelaskan tentang perceraian. Walaupun hal tersebut merupakan suatu hal yang dibenci oleh Allah, namun jika untuk kebaikan kedua belah pihak itu dihalalkan. Hal inilah yang membuatnya merasa 
yakin bahwa ajaran Islam dapat memberikan petunjuk atas semua ketentuan di kehidupan ini.

Kemudian bagi anaknya sendiri ia merubah keyakinannya pada tahun 2015. Ia merasa tidak menemukan sebuah kebenaran tentang Tuhan yang ia yakini selama ini, karena didalam alkitab disebutkan bahwa Tuhan Yesus masih mempecanyai adanya tuhan lain yang sering mereka sebut sebagai Allah Bapak, maka dari sinilah ia berpikir kepada siapa ia berdoa selama ini, dan juga tentang peribadahan yang dilakukan seperti pergi ke gereja harus adanya paksaan terlebih dahulu. Ia beranggapan bahwa beribadah ukan hanya sekedar kebutuhan melainkan kewajiban yang harus dilaksanakan seperti sholat.

Hal inilah yang memusatkan perhatiannya kepada ajaran Islam. Ia menerangkan bahwa didalam ajaran Islam semua ketentuan dan peraturan yang ada sangatlah jelas dan masuk akal. Dan ini merupakan alasannya untuk kemudian meyakinkan diri memeluk agama Islam.

Dalam memenuhi keyakinannya sebagai seorang muslim, sebagai orang tua yang mengenal Islam ada beberapa cara yang dilakukan untuk memebuhi pendidikan keagamaan bagi dirinya dan anaknya yaitu :

Pertama, sering mengajak anaknya untuk mengikuti kajian-kajian tentang ajaran Islam yang diselenggarakan oleh masyarakat sekitar atau lembaga Islam. Hal ini menurutnya akan memabantu untuk meningkatkan wawasan tentang ajaran Islam.

Kedua, sering mengajak berdiskusi dengan saudaranya yang muslim. Dari diskusi inilah muncul pertanyaan-pertanyaan mengenai ajaran Islam yang belum mereka ketahui sebelumnya. sekitar.

Ketiga, mengikuti les membaca al-Quran yang diadakan oleh DKM Mesjid

Keempat, memberikan fasilitas sekolah yang berbasis Islami. Guna membantu sang anak mendapatkan pendidikan keagamaan.

Kelima, menemui tokoh agama, dan meminta untuk mengajarkan tentang agama Islam, seprti tatacara beribadah.

Dari beberapa poin diatas dapat disimpulkan bahwa upaya yang dilakukan oleh bu RK selaku orang tua mualaf dalam memberikan pendidikan keagamaan bagi keluarganya dilakukan dengan beberapa metode dengan pola pendidikan yang bermacam-macam. Hal ini dilakukan karena minimnya pengetahuan keagamaan bu RK sehingga mencoba mecari alternatif lain untuk mendapatkan pembinaan keagamaan yang baik. Hal ini menjadikan keluarga ini meyakini lebih dalam tentang ajaran Islam, dan juga mempercayai bahwa setiap aturan yang tertulis dalam ajaran Islam ada alasan tertentu, sehingga dapat menemukan sebuah jalan ataupun solusi dari setiap kesulitan ataupun permasalahan yang ada.

\section{Pembahasan}

Berdasarkan hasil penelitian yang didapatkan terhadap dua keluarga mualaf, dipahami bahwa pembinaan keagamaan yang dilakukan oleh keluaga mualaf lebih dikhususkan dan berbeda dengan pembinaan keagaman terhadap muslim pada umumnya. Hal ini karena harus adanya penyesuaian dengan kondisi keagamaan 
para mualaf itu sendiri. Sehingga pembinaan disesuaikan dengan apa yang benarbenar belum mereka ketahui.

Pertama, pembinaan yang dilakukan oleh dua keluarga mualaf ini dilakukan dengan beberapa cara yang disesuaikan dengan situasi dan kondisi dari mualaf tersebut. Diantara yang dilakukan yaitu:

\section{a. Pembinaan secara internal}

Pembinaan yang dilakukan secara internal ini merupakan pembinaan yang dilakukan oleh dirinya sendiri dan juga keluarga sendiri. Hal ini dapat dilakukan dengan berbagai macam pola pembinaan, yakni :

1. Pemberian pemahaman keagamaan dengan contoh teladan. Pada hal ini keluarga yang mengenal agama Islam lebih dulu memberikan pemahaman keagaman melalui perilaku yang dapat dilakukan dalam sehari-hari seperti, menyegerakan sholat setelah adzan berkumandang, berpuasa. Dalam melakukan contoh teladan ini mereka dapat mendapatkan penjelasan terkait dengan hal-hal tersebut.

Dalam proses pembinaan dasar-dasar nilai keagamaan yang dilakukan ole orang tua atau keluarga terhadap anaknya ini memang cocok dengan menggunakan metode keteladanan. Hal ini merupakan aplikasi dari proses identifikasi yang sedang terjadi pada dirinya, karena keteladanan mempunyai pengaruh kecenderungan yang positif yang dapat ditiru dengan perilaku yang baik ${ }^{9}$

2. Pemberian arahan dan nasehat. Dalam pemberian arahan dan nasehat sangat diperlukan hal ini bertujuan agar para mualaf dapat mendapatkan motivasi, dukungan, bahkan solusi atas apa yang mereka ragukan dalam memahami ajaran Islam.

3. Mengajak untuk berdiskusi. Hal ini dilakukan agar mereka dapat menerima terhadap pemikiran atau penjelasan yang tidak dipahami oleh mereka. Diskusi ini biasanya dilakukan selepas magrib ataupun ketika adanya waktu luang pada saat keluarga berkumpul.

b. Pembinaan secara eksternal

Pembinaan yang dilakukan secara eksternal ini meliputi pembinaan yang diberikan dari luarkeluarga itu sendiri. seperti adanya pembinaan yang diadakan oleh tokoh agama setempat, masyarakat, bahkan lembaga-lembaga islam lainnya. Pembinaan yang dilakukan ini diantaranya adalah:

1. Pembinaan dengan cara memberikan materi tentang ajaran Islam. Pemberian materi ini biasanya dilakuakan oleh tokoh agama ataupun masyarakat atau lembaga-lembaga Islam yang disesuaikan dengan nilainilai dasar Islam. Pemberian materi ini agar mualaf dapat memahami dasar-dasar agama Islam dengan baik dan jelas. Pelaksanaannya dapat dilakukan di masjid, rumah, ataupun disuatu lembaga.

\footnotetext{
${ }^{9}$ M Dedih, U ; Yulianti, Z. ; Oky, "Pehatian Orang Tua Dalam Pendidikan Keagamaan Anak Di Rumah Hubungannya Dengan Perilaku Mereka Di Sekolah," Atthulab IV (2019): 10-11.
} 
2. Pembinaan secara personal approach, pembinaan ini dilakuakn dengan pendekatan secara pribadi. Pendekatan secara pribadi ini dilakukan antara mualaf dengan pembina (tokoh agama atau masyarakat) yang bertujuan agar adanya keterbukaan terhadap kondisi keagamaan mereka. Sehingga dapat memberikan kemudahan terhadap pembina dalam memberikan penjelasan ataupun solusi terhadap apa yang sedang dialami oleh mualaf.

3. Pembinaan secara khalaqah, pembinaan ini dilaksanakan hamper serupa dengan diskusi namun, pada hal ini pembina bersifat pasif sebagai pendengar. Dan lebih memberikan peluang bagi mualaf dalam menyampaikan beberapa tanggapan ataupun pertanyaan yang belum jelas ataupun kurang dipahami.

Kedua keluarga mualaf ini mempunyai pola pembinaan keagamaan yang berbeda, bagi keluarga pak LT, mereka memilih pola pembinaan keagamaan secara internal yang dilakukan oleh pak LT sendiri sebagai kepala keluarga, dengan bekal pengetahuan dari hasil pembinaan selama kurang lebih dua tahun dan juga pengalaman beragama selama kurang lebih belasan tahun, mengingat bahwa ada keluarga ini pak LT merupakan anggota keluarga pertama yang memeluk agama Islam. Hal inilah menjadikan bekalnya sebagai cara untuk mengajarkan keluarganya dalam mengenal Islam, walaupun ada beberapa hal yang belum ia mengerti namun, beliau selalu memberikan alternatif lain dalam mengajarkan keagamaan bagi keluarganya. Seperti menanyakan kepada tokoh agama terkait dengan hal yang belum diketahuinya.

Hal ini berbeda dengan keluarga bu RK, yang memilih pola pembinaan secara eksternal, ini dilakukan mengingat bahwa pengetahuan bu Rina dan juga pengalaman keberagamaannya masih minim, sehingga memberikan kesulitan baginya dalam mengajarkan keagamaan terhadap keluarganya. Dengan demikian beliau memberikan pengetahuan tentang keagamaan dengan bantuan dari tokoh agama, masyarakat dan lembaga keagamaan sekitar.

Pembinaan yang dilakukan oleh keluarga mualaf ini tentu saja memberikan kemudahan bagi mereka dalam memahami ajaran Islam. Hal yang paling utama yang harus didapatkan dalam pembinaan ini adalah pemahaman tentang aqidah, akhlak dan syari'ah. Karena ketiga poin ini adalah unsur terpenting dalam agama Islam. Karena dapat menyelaraskan dan juga menyeimbangkan hubungan manusia dengan Allah, hubungan manusia dengan sesama, dan hubungan manusia dengan lingkungan. Dengan pembinaan ini para muala tidak merasa terasingkan ataupun dibedakan dengan muslim pada umumnya. Karena hal ituah yang akan menghambat merek dalam mempelajari keagamaan. Maka sangatlah penting diadakannya pembinaan keagamaan bagi mualaf.

Kedua, setelah mendapatkan pembinaan keagaman mereka berpendapat bahwa apa yang diragukan dalam keyakinannya terdahulu dapat terjawab oleh agama Islam. Dari beberapa yang mereka dapatkan adalah :

a. Agama Islam sebagai agama dan petunjuk yang benar, hal ini mereka yakini karena kebenaran al-Quran yang menjelaskan tentang ke-Esaan Allah. Hal 
ini yang meyakinkan mereka dalam memilih merubah keyakinan mereka agar meraka dapat lebih dekat lagi dengan tuhannya.

b. Agama Islam merupakan solusi bagi umat Islam, hal ini terlihat dari bagaimana Islam memberikan solusi terhadap permasalah yang terjadi dalam kehidupan manusia.

c. Dapat menjadikan keimanan yang kokoh, yang dapat dilihat dari perilaku yang berubah dari sebelum mereka menjadi seorang muslim. Seperti bertaqwa kepada Allah, taat beribadah, tunduk terhadap semua peraturan dalam Islam, membenarkan apa yang disampaikan oleh Allah dan rasul-Nya, dan meninggalkan sesuatu yang dilarang oleh Allah.

Maka dapat disimpulkan bahwa agama Islam memberikan pelajaran yang penting bagi kehidupan manusia, terutama sebagai penentu dalam menjadikan kualitas pemahaman manusia yang baik yang berdampak pada kehidupan di dunia dan di akhirat. Hal inilah yang menjadikan bahwa pemikiran, ataupun pandangan yang salah pada awalnya tentang Islam, memberikan jawaban tentang pandangan tersebut dengan sebuah kebenaran yang nyata. Dan akhirnya dari pemahaman tersebut menciptakan perilaku yang sesuai dengan apa yang di syariatkan didalam agama Islam.

Pembinaan keagamaan yang dilakukan oleh mualaf ini disesuaikan dengan kondisi keagamaan mualaf tersebut. Karena bisa jadi seseorang yang melakukan konversi agama sebelumnya telah mengenal agama Islam lebih dalam sebelum memutuskan untuk masuk Islam. Namun, ada pula seseorang yang masih kurang pengetahuannya sehingga membutuhkan pembinaan yang lebih terkait dengan pemberian ajaran keagamaannya. Karena bisa jadi seorang mualaf yang sudah mempunyai bekal keagamaan dapat menjadikan ia lebih faham dan juga lebih mengerti tentang Islam dibandingkan dengan seorang muslim dari lahir. Hal ini bisa dilihat sebagaimana yang telah mereka dapatkan selama belajar tentang ajaran Islam.

Bahkan ada beberapa dari para mualaf yang dapat menjadi seorang ahli agama karena pengetahuannya dan keimanannya yang sudah mantap. Hal ini bisa terjadi karena adanya semangat dalam diri mualaf tersebut dalam mempelajari tentang Islam, sehingga menjadikannya dengan mudah untuk menerima semua pemahaman tentang ajaran Islam. Hal tersebut dapat dilihat dari pengalaman ust Felix Siauw, seorang mualaf keturuan Cina yang mendalami agama Islam dan hingga sekarang menjadikan beliau sebagai tokoh agama yang dikenal oleh banyak orang. Dari pengalaman pembelajaran keagamaan yang didapatkannya, memberikan sebuah ketenangan pada hati dan pikiran tentang kebenaran Islam, dan menjadikan keimanan yang kokoh terhadap agama Islam. 
Mahmud, Miftahul Fikri, Hasbiyallah, dan Anita N.

Pembinaan Keluarga Muallaf Upaya......

\section{Simpulan}

Berdasarkan hasil penelitian dan pembahasan dapat dikemukakan simpulan bahwa pembinaan keagamaan bagi mualaf dalam dilakukan dengan berbagai macam pola atau metode diantaranya adalah pertama, pembinaan secara Internal, yaitu pembelajaran yang didapatkan secara sendiri dan dari keluarga yang meliputi: pola keteladaaan, pemberian arahan dan nasihat, dan berdiskusi. Kedua, pembinaan secara ekternal, yaitu pembelajaran yang didapatkan dari tokoh agama, masyarakat dan juga lembaga-lembaga Islam yang meliputi : memberikan materi keagamaan, personal approach, dan metode khalaqah. Maka, dari berbagai macam polaa pembinaan ini akan memberikan kemudahan bagi para mualaf dalam memahami ajaran Islam yang disampaikan. Sehingga mereka tidak merasa terasingkan sebagai seorang yang baru mengenal Islam, karena adanya perhatian yang diberikan oleh saudara semuslim.

Dari pembinaan tersebut dapat memberikan dampak terhadap peningkatan pemahaman mualaf untuk menjadi muslim seperti pada umumnya. Seperti menemukan kebenaran tentang ke-Esaan Allah, mendapatkan solusi tentang kehidupan dan menjadikan keimanan mereka menjadi kokoh. Sehingga mereka dapat menciptakan pribadi sebagai muslim yang muttaqin dan kaffah yaitu (orang yang bertaqwa, dan mampu menjalankan semua syari'at ajaran islam, dan menghindari segala larangan-Nya). Yang sesuai dengan indikator keimanan dalam surah al-Anfal ayat 2-4. Hal ini dapat dilihat dari adanya perubahan yang dirasakan oleh kedua keluarga mualaf sebelum memahami Islam dan setelah memahami tentang Islam. Seperti, mempercayai bahwa Allah adalah Tuhan yang patut disembah, taat beribadah seperti melaksanakan sholat, dan tunduk terhadap semua perintah-Nya.

\section{DAFTAR PUSTAKA}

Dedih, U]? ; Yulianti, Z.]; Oky, M. "Pehatian Orang Tua Dalam Pendidikan Keagamaan Anak Di Rumah Hubungannya Dengan Perilaku Mereka Di Sekolah.” Atthulab IV (2019): 1011.

Eka, Ansfiksia, and Poetra Yudha. "MUALAF CENTER DESIGN AS AN IMPLEMENTATION OF PSYCHOLOGICAL" 4, no. June (2016): 37-43.

Hakim, Ramlah. "Pola Pembinaan Muallaf Di Kabupaten Sidrap Provinsi Sulawesi Selatan," 2013, 85-96.

Hazliyasyah. "MCI Catat Pertumbuhan Mualaf Di 2016 Mencapai 2.491 Orang." Republika, 2016.

Hidayati, Sri. “DI KOTA SINGKAWANG DAN SOLUSINYA” XV, no. 1 (2014): 111-36.

Mohd, Wan, Fazrul Azdi, Rose Irnawaty, Nurunnajwa Shamsudin, and Nusaibah Anuar 
Mahmud, Miftahul Fikri, Hasbiyallah, dan Anita N.

Pembinaan Keluarga Muallaf Upaya......

Musaddad. "Penerimaan Penggunaan Istilah Mualaf Dalam Kalangan Mualaf Di Malaysia" 6 (2015): 111-34.

Rahmawati, Ida, and Dinie Ratri Desiningrum. "PENGALAMAN MENJADI MUALAF?: SEBUAH INTERPRETATIVE PHENOMENOLOGICAL ANALYSIS THE EXPERIENCE OF BEING CONVERTED ( MUALAF ): AN INTERPRETATIVE PHENOMENOLOGICAL ANALYSIS" 7, no. Nomor 1 (2018).

Sodikin. “Ini Ciri-Ciri Orang Beriman Yang Sesungguhnya." Islam Pos, 2017.

Waenoful. "Kesulitan Orang Tua Mualaf Dalam Memberikan Pendidikan Agama Islam Kepada Anaknya Yang Remaja Di Yogyakarta.” UIN Sunan Kali Jaga, 2016. 